\title{
Mempertahankan Eksistensi Kampung Basen Sebagai Kampung Wisata Kerajinan Perak melalui Rumah Produktif di Era Bisnis Online
}

\author{
Tutun Seliari ${ }^{1}$, Wiyatiningsih ${ }^{2}$ \\ Universitas Kristen Duta Wacana \\ tutunseliari@staff.ukdw.ac.id \\ Universitas Kristen Duta Wacana \\ wiyatiningsih@staff.ukdw.ac.id
}

\begin{abstract}
Tourism Kampung is an alternative tourist destination for tourists who want to vacation in urban areas. Basen is a tourism kampung that was inaugurated since 2011. Basen Tourism Kampung has a major attraction as a kampung of silver artisans and silver sellers. The issues discussed in this paper is the existence of Basen as a tourism kampung that has the main attractions of silver handicrafts, not only silver products but also tourists can be involved in the process of making silver made in the occupancy community of Basen. Problems arise when the online media created a virtual transaction phenomenon of buyers and sellers, so without the physical showrooms the silver artisans and silver sellers can commercialize their products. The method used in this research is descriptive method with qualitative approach. Survey conducted to collect data. The survey targets are silver artisans and silver sellers. In-depth interviews were conducted on silver artisans and silver sellers to obtain the accuracy of the data. The result of the research shows that the important aspect in the existence of silver handicrafts in Basen is the existence of productive house in Kampung Basen and community of silver artisans and silver sellers. The productive house of the community in Kampung Basen is not only used as occupancy but also the activity of silver handicraft which became the main attraction in Basen Tourism Kampung.
\end{abstract}

Keywords: tourism kampung, existence, productive house 


\section{Pendahuluan}

Kampung Wisata Basen merupakan salah satu kampung yang terletak di kawasan Kotagede, Yogyakarta. tepatnya di Kelurahan Purbayan Kecamatan Kotagede. Kampung Wisata Basen diresmikan oleh Walikota Yogyakarta pada tanggal 23 Agustus 2011. Pengembangan Kampung Wisata Basen merupakan hasil program mahasiswa KKN PPM UGM. Apabila kita masuk ke kawasan Kampung Wisata Basen kita akan disambut oleh gapura yang bertuliskan Kampung Wisata Kerajinan Perak Basen. Di samping gapura terdapat peta sebaran lokasi para perajin yang berada di Kampung Basen. Peta tersebut tidak hanya menampilkan sebaran industri rumahan perajin perak tetapi juga industri rumahan kerajinan lain seperti kayu, logam, box, dan kuliner. Melalui peta tersebut kita dapat dengan mudah mengetahui lokasi para perajin. Kita juga dapat dengan mudah menjumpai artshop kerajinan perak yang berada di sepanjang Jl. Kemasan. Namun jika kita masuk lebih dalam lagi ke dalam Kampung Basen kita akan mendapati permukiman penduduk dengan suasana kampung perkotaan. Bayangan kita yang tadinya masuk ke kampung wisata akan mendapati artshop kerajinan perak tidak akan langsung kita dapatkan. Hal inilah yang kadang membuat kecewa wisatawan. Wisatawan harus mendatangi langsung ke rumah-rumah perajin ataupun penjual perak untuk mendapatkan kerajinan perak. Untuk mempermudah wisatawan di setiap titiktitik strategis terdapat signage yang memudahkan wisatawan mengetahui lokasi para perajin perak. Branding Kampung Wisata Basen sebagai kampung wisata berbasis industry kecil yang mayoritas kerajinan perak menuntut masyarakat Basen dalam daya dukungnya menerima kedatangan wisatawan.

Dalam Peraturan Walikota Yogyakarta No 115 Th 2016, Kampung Wisata adalah suatu wilayah yang penduduknya mempunyai kegiatan di bidang sosial dan ekonomi dalam bentuk pengembangan usaha pariwisata yang berbasis pada potensi daya tarik alam dan buatan termasuk bangunan cagar budaya maupun tatanan sosial kehidupan masyarakat setempat, nilai budaya, dan seni tradisi serta kerajinan dan kuliner tradisional dan sarana prasarana akomodasi. Menurut Pranatasari (2016), eksistensi suatu wisata merupakan salah satu pendukung dalam pencapaian penciptaan peluang usaha bagi masyarakat yang berada di sekitar wilayah wisata. Eksistensi sendiri secara etimologis berarti keberadaan akurat. Sedangkan secara terminologi, yaitu segala sesuatu (apa saja) yang di dalam menekankan bahwa susuatu itu ada. Eksistensi suatu wisata banyak memperoleh manfaat baik dari masyarakat lokal maupun bagi pemerintah daerah.

Wisatawan datang ke kampung dengan tujuan utama untuk melihat hasil produksi kerajinan perak dan proses pembuatannya. Hal tersebut mengakibatkan kebutuhan ruang secara fisik. Kebutuhan ruang pamer untuk display dan memasarkan hasil produksi serta kebutuhan ruang kerja agar wisatawan dapat melihat langsung proses produksi kerajinan perak. Sebagian besar perajin perak di kampung Basen melakukan kegiatan produksi dan pemasarannya menjadi satu dengan unit hunian. Menurut Johan Silas (1993) dalam Osman dan Amin (2012), konsep rumah dan kerja termasuk dimensi sosial dan budaya. 
Beberapa detail fungsi rumah dapat diuraikan sebagai berikut:

- Rumah (saja): yaitu tipe rumah yang digunakan sebagai tempat tinggal tanpa kegiatan lain yang berarti. Pada tipe ini umumnya untuk golongan berpenghasilan menengah ke atas, tetapi sedikit sekali golongan berpenghasilan rendah menggunakannya.

- Rumah Produktif: pada tipe ini sebagian dari rumah digunakan untuk usaha (produktif) atau kegiatan ekonomi.

Berdasarkan hal tersebut dapat dikatakan bahwa rumah warga di permukiman Kampung Basen sebagian besar merupakan rumah produktif.

Pemasaran produk kerajinan sekarang ini telah meluas sampai keluar negeri semenjak diadakanya pasar global. Komputer dapat digunakan untuk pengawasan proses (control process) jadi semua teknologi tersebut tidak menggunakan sistem manual atau dijalankan oleh manusia. Salah satu kemampuan penguasaan teknologi yang perlu dikembangkan adalah sistem komputerisasi dan internet (interconnection networking), karena computer (personal computer) dan internet secara umum, telah digunakan masyarakat sebagai sarana informasi dan digunakan sebagai sarana bisnis untuk memasarkan suatu produk tertentu. (Muslihudin,2013). Menurut Indrajit (2002) Ada dua hal utama yang biasa dilakukan oleh konsumen di dunia maya (arena transaksi yang terbentuk karena adanya jaringan internet). Pertama adalah melihat produk-produk atau jasajasa yang diiklankan oleh perusahaan terkait melalui website-nya. Kedua adalah mencari data atau informasi tertentu yang dibutuhkan sehubungan dengan proses transaksi bisnis atau dagang (jual beli) yang akan dilakukan. Jika tertarik dengan produk atau jasa yang ditawarkan, konsumen dapat melakukan transaksi perdagangan dengan dua cara. Cara pertama adalah secara konvensional seperti yang selama ini dilakukan, baik melalui telepon, faks, atau langsung datang ke tempat penjualan produk atau jasa terkait. Cara kedua adalah melakukan pemesanan secara elektronik, yaitu dengan menggunakan perangkat komputer yang dapat ditemukan dimana saja (rumah, sekolah, tempat kerja, warnet, dsb). Berdasarkan pesanan tersebut, penjual produk atau jasa akan mendistribusikan barangnya kepada konsumen.

Adanya kemudahan pemasaran produk kerajinan perak melalui media online memberi pengaruh terhadap ketersediaan ruang pamer dan ruang produksi kerajinan secara fisik di Kampung Wisata Basen. Permasalahan muncul ketika dengan media online tercipta fenomena ruang virtual pertemuan pembeli dan penjual. sehingga tanpa ruang pamer yang fisik para perajin dapat memasarkan hasil kerajinannya. Para perajin dan penjual tidak tergantung oleh pembeli yang datang ke rumahnya untuk memesan ataupun membeli hasil produknya padahal ketersediaan ruang pamer dan ruang workshop kerajinan perak secara fisik sangat diperlukan dalam mendukung eksistensi Kampung Basen sebagai Kampung Wisata.

\section{Metode}

Tulisan ini diangkat berdasarkan penelitian yang dilakukan terhadap Kampung Basen. Metode yang digunakan yaitu penelitian deskriptif, yaitu jenis penelitian yang memberikan gambaran atau uraian atas suatu keadaan sejelas mungkin tanpa ada 
perlakuan terhadap objek yang diteliti. Menurut Sukmadinata (2007), penelitian deskriptif adalah metode penelitian yang ditujukan untuk menggambarkan fenomena-fenomena yang ada yang berlangsung pada saat ini atau saat yang lampau. Penelitian ini bermaksud untuk mendapatkan deskripsi dan gambaran mengenai eksistensi Kampung Wisata Basen, sifat pendekatan penelitian ini termasuk dalam penelitian kualitatif. Pendekatan kualitatif dilakukan dengan melihat fenomena yang ada di lapangan kemudian dianalisis berdasarkan teori yang relevan, data, dan fakta. Pengumpulan data dilakukan dengan menggunakan metode observasi, wawancara terhadap tokoh dan perajin perak, dokumen dan studi pustaka. Analisis data spasial juga dilakukan untuk mengetahui hubungan aktivitas produksi dan display kerajinan perak yang merupakan atraksi utama di Kampung Basen, terhadap hunian para perajin. Studi kasus yang dipilih secara selektif (purposive sampling), yaitu enam unit hunian perajin perak yang berada di dalam Kampung Basen. Pada Gambar 1 dapat dilihat titik-titik pada peta merupakan titik-titik hunian perajin dan penjual perak. Titik lokasi hunian perajin dan penjual kerajinan perak yang menjadi amatan adalah titik yang berwarna gelap.

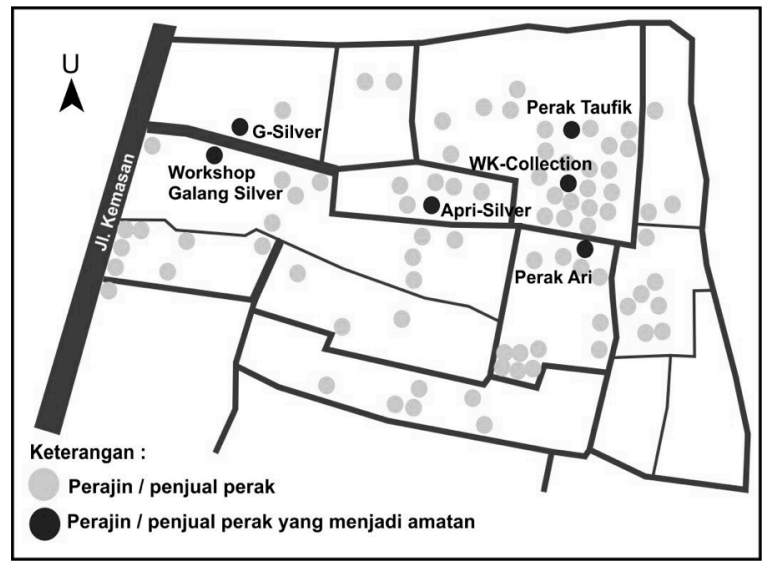

Gambar 1. Peta Lokasi Perajin Kampung Wisata Basen

(Sumber: diolah dari data primer, 2017)

\section{Hasil dan Pembahasan}

A. Kerajinan perak sebagai atraksi utama Kampung Wisata Basen

Para pelaku usaha industri kecil di Kampung Basen tersebut tergabung dalam organisasi Senopati (Asosiasi Pengusaha Desa Wisata Basen). Senopati merupakan wadah kepengurusan di tingkat RW yang menaungi semua pelaku usaha kreatif kecil dan menengah di wilayah kampung Basen. Sejak 2011 Kampung Basen diresmikan oleh Walikota Yogyakarta menjadi Kampung Wisata yang mempunyai atraksi utama sebagai kampung perajin perak. Saat memasuki Kampung Wisata Basen kita akan dengan mudah menemukan peta keberadaan lokasi perajin dan penjual perak. Di setiap rumah perajin dan pemilik industri kecil juga terdapat papan nama jenis usaha dan nama usahanya tersebut. Di Kampung Basen tidak hanya terdapat industri kecil perak tetapi beragam industri kecil lain, antara lain logam, kuliner, kerajinan tanduk, kerajinan box dan kayu, dan konveksi.

Keberadaan perajin perak di Kampung Basen merupakan atraksi utama 
Kampung Basen sebagai Kampung Wisata. Berdasarkan wawancara terhadap mantan Ketua organisasi Senopati, Bapak Bambang Mursanyoto (wawancara tanggal 20 Juli 2017), beliau mengatakan bahwa pada mulanya inisiasi Kampung Wisata Basen dimulai saat ada pendampingan dari KKN UGM. Pada awalnya terdapat 75 perajin perak, namun saat ini mulai menurun karena industri kerajinan perak turun naik. Saat ini predikat Kampung Basen sebagai kampung wisata hanya terkesan sebagai label saja, saat pengagasan konsep kampung wisata harapannya branding tersebut dapat mengangkat Kampung Basen dan dapat meningkatkan income masyarakat Basen dengan adanya kunjungan dari wisatawan. Bahkan dahulu Kampung Basen juga mempunyai sebuah website (www.rwoubasen.com) untuk mempromosikan kampung wisata dan kerajinan peraknya, namun saat ini website tersebut sudah tidak dapat diakses karena sudah tidak ada yang mengelolanya. Hal tersebut juga diungkapkan saat wawancara terhadap Ketua organisasi Senopati periode saat ini, yaitu Bapak Purnomo. Bapak Purnomo (wawancara tanggal 20 Juli 2017) mengungkapkan bahwa branding Kampung Wisata belum mempunyai pengaruh yang signifikan khususnya terhadap perajin, karena saat ini perajin dalam melakukan pemasaran ataupun jual beli masih secara pribadi. Berdasarkan diskusi dari kedua tokoh tersebut dan observasi di lapangan dapat dipetakan tipologi pelaku industri kreatif perak di Kampung Basen yaitu :

1. Perajin perak, pelaku kegiatan industri kreatif kerajinan perak yang berperan sebagai pembuat kerajinan perak, mendapatkan order dari orang lain, baik dari penjual perak, wisatawan, ataupun pemesan.
2. Penjual perak, pelaku kegiatan industri kreatif kerajinan perak yang barang produksinya disuplai / mengambil dari perajin perak untuk dijual ke customer.

3. Perajin dan penjual, pelaku kegiatan industri kreatif kerajinan perak yang membuat produksi kerajinan perak dan menjualnya kepada customer dan wisatawan.

\section{B. Rumah produktif perajin dan penjual kerajinan perak}

Sebagian besar perajin di Kampung Wisata Basen memasarkan produk kerajinan peraknya melalui media online. Dengan kecanggihan teknologi saat ini mereka dapat dengan mudah langsung berinteraksi dengan customer dalam ruang virtual, sehingga mereka tidak harus berlama-lama menunggu wisatawan atau pembeli datang ke toko atau rumah mereka.

Branding Kampung Basen sebagai kampung wisata berbasis industri kecil menuntut kesiapan masyarakat Kampung Basen dalam daya dukungnya menerima kedatangan wisatawan. Wisatawan datang ke kampung dengan tujuan utama untuk melihat hasil produksi kerajinan perak dan proses pembuatannya. Hal tersebut mengakibatkan kebutuhan ruang secara fisik. Kebutuhan ruang pamer untuk display dan memasarkan hasil produksi serta kebutuhan ruang kerja agar wisatawan dapat melihat langsung proses produksi kerajinan perak. Sebagian besar perajin perak di kampung Basen melakukan kegiatan produksi dan pemasarannya menjadi satu dengan unit hunian. Pada tulisan ini akan dibahas enam unit hunian rumah produktif perajin dan penjual perak, dimana rumah produktif perajin dan penjual perak merupakan aspek yang 
penting dalam mendukung eksistensi Kampung Basen sebagai Kampung Wisata.

\section{Perak Ari}

Perak Ari juga berlokasi di dalam kampung Basen. Pemilik Perak Ari bernama Ari dan berusia 34 tahun. Perak Ari hanya memproduksi kerajinan berupa perak, antara lain cincin dan liontin. Perak Ari memsarkan hasil produksinya langsung kepada konsumen dan kepada penjual perak lainnya. Selain dengan gethok tular, Perak Ari memasarkan hasil produksinya melalui media sosial BBM dan Whatsapp, selain itu juga menggunakan Facebook dengan akun Ari Silver. Perak Ari merasa dimudahkan dengan pemasaran via online. Dia juga berharap bahwa konsumen yang membeli secara online untuk datang ke rumahnya untuk memastikan bahwa perak yang dibuatnya dia kerjakan sendiri. Menurut Ari predikat Kampung Wisata Basen belum memberikan pengaruh yang lebih terhadap penjualan hasil peraknya, konsumen hanya melihatlihat namun belum sampai memesan.

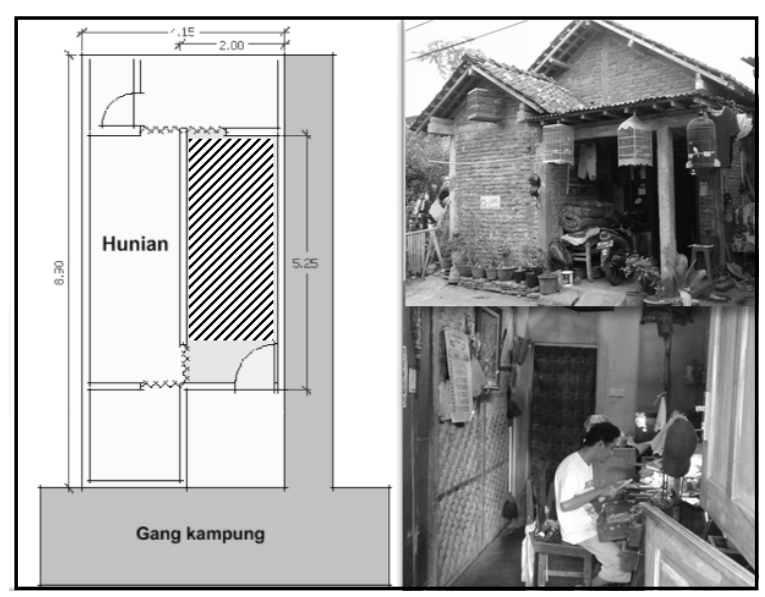

Gambar 2. Layout Rumah Produktif Perak Ari

(Sumber: data primer, 2017)

Berdasarkan pada Gambar 2, bisa dilihat bahwa kegiatan produksi Perak Ari (pada bagian gambar yang diarsir) menjadi satu dengan unit hunian. Kegiatan produksi perak dilakukan pada ruang utama rumah tersebut. Ruang utama dalam rumah Ari menampung berbagai aktivitas selain produksi perak, antara lain ruang menerima tamu, makan, dan kegiatan santai. Apabila kita berkunjung ke Perak Ari kita dapat melihat langsung proses pembuatan perak yang dilakukan oleh Ari. Beberapa hasil karyanya dapat kita lihat di meja kerjanya. Belum ada ruang khusus untuk mendisplay hasil pekerjaan perak nya. Perak Ari mempunyai spesialis pembuatan cincin. Akses utama bagi pengunjung Perak Ari menjadi satu dengan akses penghuni rumah.

\section{Perak Taufik}

Perak Taufik berada di dalam kampung Basen tepatnya di RT 04. Di RT 04 ini terdapat paling bnayak perajin perak di Kampung Basen, salah satunya Perak Taufik yang dimiliki oleh Muhammad Taufik. Taufik masih berusia cukup muda dibandingkan dengan para perajin perak lainnya, yaitu 29 tahun. Perak Taufik memproduksi kerajinan perak berupa cincin, gelang, liontin. Selain perak kerajinan lain yang dihasilkan bermaterial logam emas dan palladium. Perak Taufik memasarkan hasil produksinya kepada pemesan langsung, costumer online dan penjual perak lainnya. Selain memasarkannya secara gethok tular,Perak Taufik memasarkannya melalui media online antara lain Instagram : Perak Taufik, Website : www.peraktaufik.co.id, Blog : Jogja Ring online, Tokopedia : Perak Taufik. Perak Taufik merasa dimudahkan dalam pemasaran menggunakan media online ini, dan dia berharap pembeli online juga datang ke workshopnya untuk melihat karyanya yang lain dan bagaimana cara untuk pembuatan kerajinan perak tersebut. Sebelumnya 
produksi kerajian Perak Taufik berada dalam ruang produksi yang menjadi satu dengan unit hunian pemilik. Namun saat ini karena orderan meningkat terutama order dari media online, Perak Taufik mengembangkan ruang produksinya terpisah dengan unit hunian.

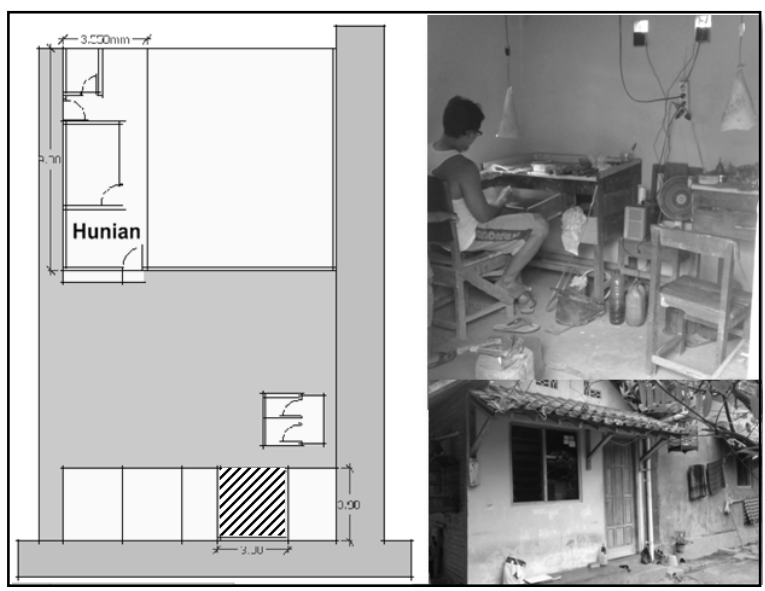

Gambar 3. Layout Rumah Produktif Perak Taufik

(Sumber: data primer, 2017)

Berdasarkan Gambar 3, dapat dilihat bahwa pada bagian gambar yang diarsir merupakan pengembangan ruang pada Perak Taufik untuk kegiatan produksi perak. Apabila kita berkunjung ke Perak Taufik kita bisa melihat proses pembuatan perak di ruang produksi. Ruang produksi/workshop tersebut dapat diakses dari sisi hunian Perak Taufik sehingga apabila wisatawan ataupun ada pengunjung yang melewati gang tidak mudah mengetahui bahwa ada workshop perak disana karena orientasi bangunan workshop menghadap ke hunian, bukan ke gang kampung.

\section{WK Collection}

WK Collection berada di dalam kampung Basen RT 04. Pemilik WK Collection adalah Ibu Karwiyati, usahanya dibantu oleh anaknya Wijayanto yang berusia 36 tahun. Kegiatan usaha perak di WK
Collection yaitu sebagai penjual perak. WK Collection mempunyai strategi penjualan perak secara offline dan online. Secara offline mereka mempunyai 2 etalase yang dipajang di rumahnya menjadi satu dengan unit hunian, dan mempunyai 2 kios di XT square (lokasinya $1 \mathrm{~km}$ dari Kampung Basen). Selain perak WK Collection juga menjual berbagai barang asesoris lainnya antara lain miniatur, kerajinan logam tembaga dan kuningan. Secara online WK Collection sudah mempunya website sendiri yaitu di laman www.wkcollection.com. Selain itu WK Collection juga menjual produknya melalui media sosial antara lain Instagram dengan akun wkcollection70674, Facebook dengan akun wkcollection70674, dan tokopedia : www.tokopedia.com/wkcollection. WK Collection juga menerima pesanan kerajinan perak, biasanya order yang diterima akan di orderkan ke perajin perak rekanannya. Menurut Wijayanto, mempunyai website sangat memberikan pengaruh yang besar dalam usaha peraknya, karena saat ini banyak konsumen yang membeli secara online. Distribusi penjualan perak WK Collection bahkan sudah hingga ke mancanegara yaitu ke Italy. Jika sedang menangani orderan export, WK Collection bisa melibatkan perajin perak hingga 25 orang 


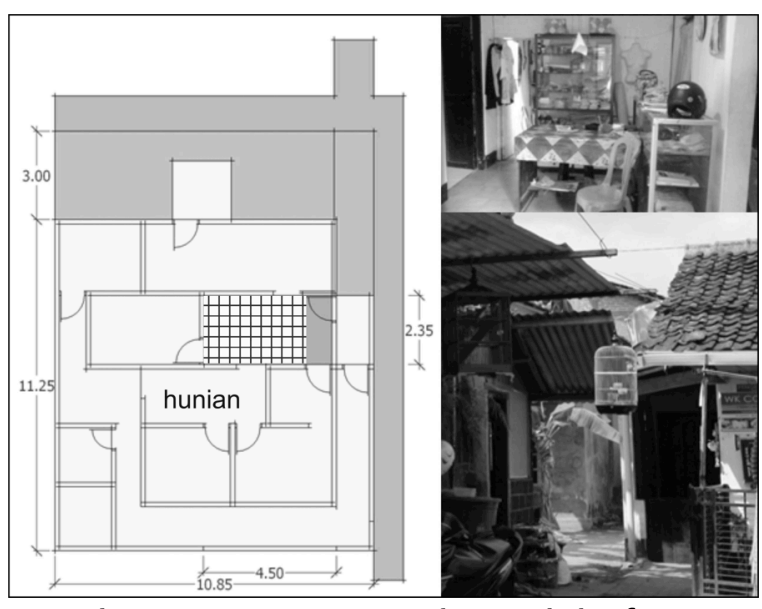

Gambar 4. Layout Rumah Produktif WKCollection

(Sumber: data primer, 2017)

Berdasarkan Gambar 4, dapat dilihat bahwa pada bagian yang diarsir pada layout rumah produktif WK-Collection digunakan untuk ruang pamer display barang kerajinan perak dan asesoris didekatkan dengan sirkulasi masuk hunian agar pengunjung mudah mengaksesnya.

\section{Apri Silver}

Pemilik Apri Silver adalah Bapak Pribadi. Lokasi Apri Silver berada di tepi gang utama kampung Basen. Apri Silver menjual berbagai produk kerajinan perak. Ruang pamer Apri Silver berada satu unit hunian dengan rumah pemilik. (Bisa dilihat bagian yang diarsir kotak pada Gambar 5).

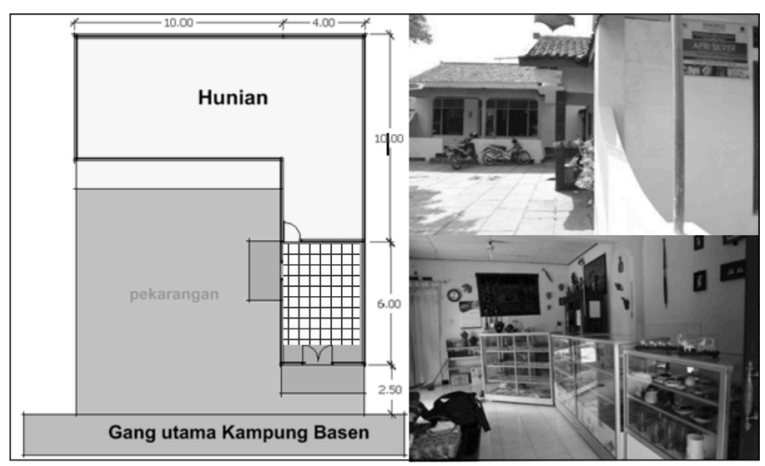

Gambar 5. Layout Rumah Produktif Apri Silver

(Sumber: data primer, 2017)
Jika kita melalui gang utama Kampung Basen kita akan dengan mudah menemukan keberadaan Apri Silver. Kita dimudahkan dengan adanya papan nama dan orientasi ruang pamer Apri Silver menghadap ke jalan gang utama. Apri Silver mempunyai koleksi yang sangat lengkap mulai dari cincin perak hingga asesoris logam lainnya. Namun di Apri Silver kita hanya bisa melihat barang perak yang sudah jadi karena di Apri Silver hanya menjual perak tidak memproduksi kerajinan perak.

\section{G-Silver}

Usaha kerajinan perak G-Silver berawal dari usaha keluarga yang dirintis oleh Bapak Margono sejak tahun 1979 dan saat ini diteruskan oleh putranya yaitu Bapak Bambang Mursanyoto. Selain perak G-Silver memproduksi kerajinan logam yang lain berupa kuningan dan tembaga. Produk kerajinan yang dihasilkan antara lain perhiasan, miniatur, hiasan, alat rumah tangga. Lokasi G Silver berada di tepi gang utama jalan masuk Kampung Basen. Selain memasarkannya secara langsung ke konsumen dan secara online, G-Silver menitipkan hasil produk peraknya ke toko-toko lain. Berdasarkan Gambar 6 dapat kita lihat ruang produksi (arsir garis diagonal) dan ruang pamer (arsir persegi) dari kerajinan G-Silver menjadi satu dengan unit hunian pemilik, dan berada di belakang dari hunian utama (rumah keluarga besar). Sehingga jika dilihat dari gang utama tidak terlihat aktifitas para perajin perak ataupun ruang pamer G-Silver. Kita bisa mengetahui bahwa di hunian tersebut ada aktivitas kerajinan perak dari papan nama yang berada di tepi gang utama. Cukup menarik jika mengunjungi G-Silver karena dalam satu tempat kita bisa melihat aktivitas produksi pembuatan kerajinan perak dan juga banyak barang 
jadi yang di display. Namun untuk sekarang ini tidak setiap hari ada kegiatan aktivitas pembuatan kerajinan perak, tergantung apakah ada order atau tidak.

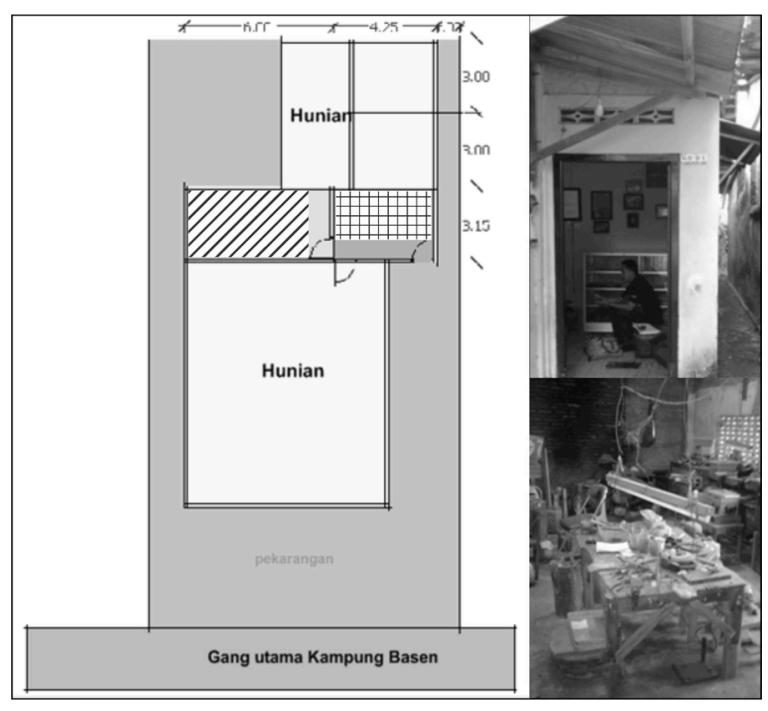

Gambar 6. Layout Rumah Produktif GSilver

(Sumber: data primer, 2017)

\section{Galang Silver 925}

Workshop Galang Silver 925 berada di tepi gang utama jalan masuk Kampung Basen. Saat kita masuk Gang utama Kampung Basen akan dengan mudah kita untuk menemukan workshop Galang Silver 925 karena terdapat papan nama penunjuk yang mudah dijumpai di pinggir jalan, namun aktivitas perajin perak baru akan dijumpai jika kita masuk ke ruang workshop nya. Ruang Workshop Galang Silver menjadi satu unit hunian dengan rumah pemilik nya yaitu Bapak Ibnu dan Ibu Helmi.

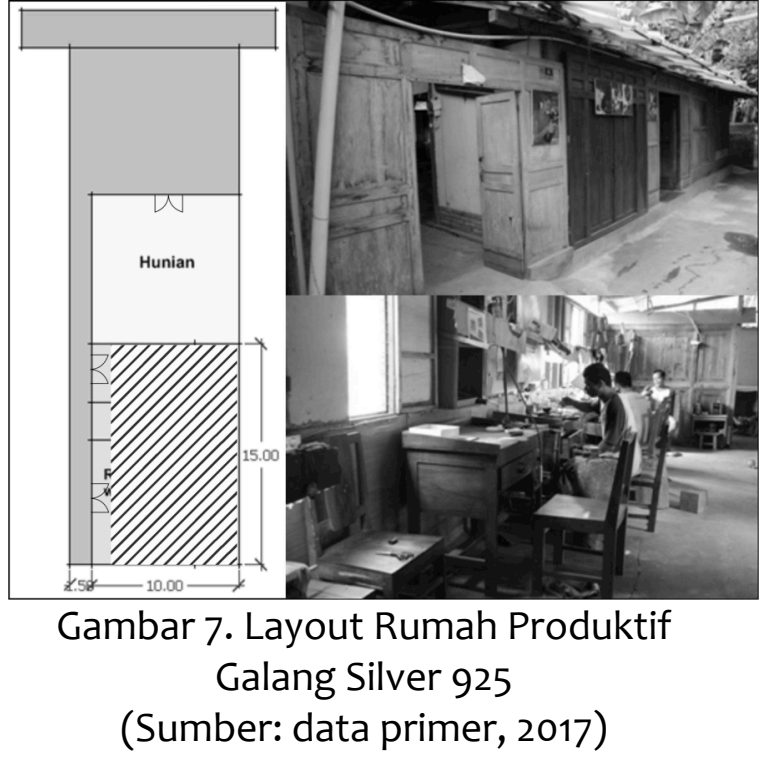

Ruang Workshop Galang Silver 925 berada di belakang unit hunian pemilik.(Bisa dilihat bagian yang diarsir pada Gambar 7). Walaupun menjadi satu namun akses bagi pengunjung dan pemilik hunian berbeda, jika mendatangi Workshop Galang Silver kita bisa langsung mengakses ruang workshopnya. Galang Silver 925 mempunyai 7 orang karyawan yang bekerja di ruang produksi / workshop. Galang Silver 925 mempunyai tempat display tidak jauh dari ruang workshop yaitu di tepi Jalan Utama menuju Kotagede yaitu Jalan Kemasan (kurang lebih 10om dari ruang workshop).

Selain perak, Galang Silver 925 juga menjual dan memproduksi emas. Pemasaran hasil produksi kerajinan perak dan emas dari Galang Silver langsung ke konsumen dan wisatawan. Galang Silver 925 memasarkan hasil produksinya melalui group BBM dan Whatasapp dan juga situs online : www.galangsilver925.com. Dengan pemasaran via online Galang Silver 925 merasa dimudahkan dalam memasarkan produknya. Menurut Galang Silver predikat kampung Basen sebagai Kampung Wisata mempunyai pengaruh terhadap penjualan hasil produk 
kerajinan yang dihasilkan oleh Galang Silver 925.

\section{Rumah produktif sebagai aspek pendukung eksistensi kampung wisata} Melalui pembahasan diatas dapat diketahui bahwa perajin perak di Kampung Wisata Basen sudah menggunakan media online untuk mempromosikan dan menjual barang kerajinan perak. Mereka memanfaatkan e-commerce (dalam hal ini website dan emarketplace tokopedia) untuk memasarkan kerajinan perak, yang lainnya masih menggunakan media sosial. Promosi dan penjualan melalui media internet gencar dilakukan pelaku kerajinan perak karena dengan media internet jangkauan terhadap konsumen semakin luas. Salah satu pengaruh secara langsung media online terhadap hunian bisa kita lihat secara langsung pada Perak Taufik. Perak Taufik lebih banyak mendapatkan orderan perak dari online, untuk menunjang pekerjaannya tersebut dia ekspansi ruang workshopnya dekat dengan hunian nya, untuk mewadahi aktivitas produksi kerajinan perak. Berdasarkan keterangan para perajin konsumen yang order dengan media online melalui ecommerce ataupun media sosial jika lokasinya masih di seputaran Yogyakarta mereka akan datang langsung saat pengambilan barang ataupun sekedar datang melihat dan mengecek proses pengerjaan pesanannya.

Keberadaan rumah-rumah produktif para perajin dan penjual perak inilah yang menjadi tujuan utama kunjungan di Kampung Wisata Basen karena di tempat tersebut terdapat atraksi yang menarik yaitu kerajinan perak dan proses pembuatan kerajinan perak. Melalui media online tersebut diharapkan juga akan meningkatkan kunjungan wisatawan ke Kampung Basen. Jika kita melihat hunian perajin dan penjual perak yang sudah dibahas, tidak semua menyediakan ruang display untuk memamerkan hasil kerajinan perak. Sebagian besar perajin terutama yang berprofesi hanya sebagai perajin belum mempunyai ruang display. Ruang display secara fisik cukup penting karena pengunjung ataupun wisatawan yang berkunjung ke Kampung Basen sebagian besar tujuan utamanya mencari barang jadi kerajinan perak. Ruang Display tidak berarti harus seperti ruangan khusus tersendiri, misalnya sebuah etalase display yang memamerkan hasil karya yang pernah dibuat perajin perak. Tren wisata minat khusus saat ini juga mendorong wisatawan yang berkunjung ke suatu destinasi untuk mendapatkan sebuah pengetahuan dan experience. Hal tersebut yang bisa kita dapatkan saat berkunjung ke workshop para perajin perak. Kita bisa bertanya tentang proses pembuatan sebuah kerajinan perak dan bahkan juga bisa mencoba membuatnya. Di Kampung Wisata Basen Pengunjung sangat dibantu dengan keberadaan papan nama yang terpasang di depan hunian perajin atau penjual sehingga pengunjung dapat mengetahui hunian tersebut terdapat aktivitas kerajinan perak atau tidak, karena tidak semua aktivitas kerajinan perak dalam hunian bisa terlihat dari gang/jalan.

Seiring berjalannya waktu dan perkembangan bisnis online yang meningkat secara tidak langsung hal tersebut mempengaruhi perkembangan pola ruang rumah produktif hunian para perajin dan penjual perak. Dari pembahasan bisa kita simpulkan ada tiga hal yang dilakukan perajin ataupun penjual perak terkait dengan perkembangan hunian dan 
mengakomodir kegiatan produksi ataupun penjualan perak, yaitu :

- ekspansi unit hunian dengan menambah ruang baru seperti yang dilakukan oleh Perak Taufik

- menggunakan ruang yang sudah ada digunakan bersama dengan aktivitas kerajinan perak seperti yang dilakukan oleh Perak Ari

- mempunyai ruang di wilayah lain atau jauh dari unit huniannya untuk pengembangan aktivitas kerajinan perak seperti yang dilakukan oleh Galang Silver 925.

Tantangan bagi Kampung Basen terhadap rumah-rumah produktif perajin dan penjual perak dalam perannya menjaga eksistensi Kampung Wisata Basen adalah arahan perkembangan rumah-rumah produktif tersebut. Sebagai contoh yang terjadi di Perak Taufik, perkembangan ruang baru dilakukan dengan mengekspansi di luar unit hunian. Namun orientasi bangunan tersebut menghadap ke unit hunian karena kemudahan akses penghuni dari dalam hunian, belum berdasarkan aspek pengunjung dari luar yang aksesnya dari gang kampung sehingga akan menarik jika terdapat akses juga dari gang kampung. Sehingga aksesibilitas pengunjung akan dengan mudah mencapai tempat tersebut. Hal tersebut dapat kita lihat di Apri Silver, ruang display pada Apri Silver yang berada di tepi gang utama Kampung Basen sangat mudah diakses oleh pengunjung. Pengunjung yang berada di gang pun dengan mudah bisa melihat ruang display Apri Silver sehingga menarik pengunjung untuk mampir dan melihatlihat atau membeli koleksinya. Kemudahan akses pengunjung kerumahrumah perajin ataupun penjual perak tidak hanya dimudahkan melalui peta dan papan nama saja, tetapi orientasi bangunan dan jalur sirkulasi sangat mempengaruhi. Hal ini diperlukan kesadaran dari masing-masing pribadi perajin ataupun penjual kerajinan perak di Kampung Basen sehingga ketika nantinya mereka mengembangkan unit huniannya semua akan terintegrasi mendukung eksistensi keberadaan Kampung Wisata Basen. Meningkatkan kesiapan para perajin dan penjual dalam menerima kunjungan baik wisatawan ataupun pengunjung yang ingin memesan perak juga perlu dilakukan. Hal ini dirasa perlu agar pengunjung ataupun wisatawan merasa nyaman berada di Kampung Basen.

\section{Usaha masyarakat kampung Basen dalam eksistensi kampung wisata}

Para pelaku usaha kerajinan perak di Kampung Basen tergabung dalam komunitas Senopati dan kelompok UMKM. Senopati merupakan komunitas yang mewadahi pelaku usaha kreatif kecil dan menengah di wilayah kampung Basen. Bisnis perak di Kotagede mengalami naik turun mengikuti tren yang sedang berkembang dan kebutuhan di pasaran, begitu juga dengan keberadaan KAmpung Wisata Basen. Walaupun demikian beberapa usaha yang sudah dilakukan masyarakat Kampung Basen untuk tetap mempertahankan eksistensinya adalah :

1. Perajin dengan aktif terlibat dalam kegiatan komunitas, antara lain komunitas Senopati dan Kelompok UMKM. Komunitas tersebut melakukan pertemuan rutin secara berkala untuk membahas kemajuan dan kegiatan dari masing-masing usaha para perajin.

2. Bekerja sama dengan pemerintah, seperti yang dilakukan oleh Bapak Bambang melalui komunitas Senopati mengikuti pameran yang diadakan oleh Dinas Perindagkoptan di daerah- 
daerah luar Yogyakarta untuk memperkenalkan kerajinan perak Basen Kotagede.

3. Bekerja sama dengan sekolah-sekolah untuk melakukan kunjungan ke Kampung Wisata Basen.

4. Anggota komunitas / kelompok mengikuti pelatihan-pelatihan yang diadakan oleh komunitas bekerja sama dengan stakeholder, misalnya seperti Perak Taufik yang mengikuti pelatihan marketing online yang dilaksanakan atas kerjasama komunitas dengan salah satu bank terbesar milik pemerintah.

\section{Kesimpulan}

Berdasarkan pada analisis dan pembahasan diatas dapat disimpulkan bahwa:

1. Keberadaan rumah produktif di Kampung Basen merupakan aspek yang sangat penting dalam eksistensi kerajinan perak di Kampung Wisata Basen.

2. Rumah produktif masyarakat di Kampung Basen tidak hanya digunakan sebagai Hunian tetapi juga aktivitas kerajinan perak yang menjadi atraksi utama di Kampung Wisata Basen.

3. Komunitas Senopati dan Kelompok UMKM menjadi sebuah wadah yang sangat penting bagi para perajin dalam berkarya mengembangkan usahanya dan dalam rangka mempertahankan eksistensi Kampung Wisata BAsen.

Saran bagi pengembangan Kampung Wisata Basen adalah :

1. Menggiatkan kembali komunitas Senopati sebagai komunitas yang mewadahi perajin perak di Kampung Basen.

2. Mengaktifkan kembali website yang dulu sudah dipunyai oleh Kampung
Wisata Basen, sebagai sarana promosi dan memperkenalkan Kampung Basen sebagai Kampung perajin perak dan memasarkan hasil kerajinan perak.

3. Arahan atau guide line desain pengembangan hunian untuk mendukung eksistensi Kampung Basen sebagai Kampung Wisata.

\section{Daftar Pustaka}

Azahra, dan Khadiyanto. 2013. Pengaruh Keberadaan Desa Wisata Terhadap peningkatan kesejahteraan Masyarakat (S tudi Kasus : Desa Karang Tengah, Kabupaten Bantul). Jurnal Ruang, Vol. I, No I, Hal. 51-60.

Indrajit, Richardus Eko. (2002). Electronic Commerce : Strategi dan Konsep Bisnis di Dunia Maya. Aptikom.

Muslihudin, M. (2013). Sistem Informasi Penjualan Batik Basurek Berbasis Web Pada Basurek Collection Bengkulu. Jurnal TAM (Technology Acceptance Model), Vol. 1, Hal 48-52.

Osman, dan Amin. (2012). "Rumah Produktif : Sebagai Tempat Tinggal dan Tempat Bekerja di Permukiman Komunitas Pengrajin Emas (Pola Pemanfaatan Ruang Pada Usaha Rumah Tangga)." Prosiding 2012 Hasil Penelitian Fakultas Teknik, Volume 6 : Desember 2012. Jurusan Arsitektur Universitas Hasanuddin.

Peraturan Walikota Yogyakarta No 115 Th 2016 tentang Penyelenggaraan Kampung Wisata.

Pranatasari, D. (2016). Eksistensi Taman Agrowisata Dan Kewirausahaan Sosial. J+PLUS UNESA, Vol. 5, No. 2, Hal. 1-9.

Sukmadinata, Nana Syaodih. (2007). Metode Penelitian Pendidikan. Bandung : Remaja Rosdakarya. 